\title{
Science and War Through the Ages
}

\author{
Benjamín Ruiz Loyola* \\ Faculty of Chemistry, UNAM National Autonomous University of Mexico, USA
}

Received: 畊 October 11, 2018; Published: 眥 October 16, 2018

*Corresponding author: Benjamín Ruiz Loyola, Faculty of Chemistry, UNAM National Autonomous University of Mexico, Av. Universidad 3000, Copilco el Alto, Coyoacán, 04650, Cd. Mx, USA

\section{Opinion}

In all animal species competition between individuals is presented to obtain mainly food and reproduction; When there are not enough satisfiers, there are disputes that usually stop when there is a winner, without individuals dying. The defeated one retires, and the winner is satisfied with the victory and, eventually, with the dominion over the rest of the group, which implies that he will eat and mate before the others. So far, animals do not have too much trouble. But the human is a very special animal, because he has a memory.

Remembering the past allows you to anticipate the future; the loser analyzes the reasons that made his opponent win and plans how to win in the next match. The winner does the same to strengthen their strengths, overcome the weak and anticipate the actions of the opponent, exactly as in a game of chess. It then presents the convenience of killing the loser, in order to avoid his rematch and let future challengers know what to expect. When it is evident that a combat between individuals anticipates a defeat, it is sought to go for reinforcements thus forming the first armies, often initiated by groups of losers who seek to defeat the former winner. And so, a chain is generated. In a short time, human beings begin to wage war not because the species is more violent, but because it is more intelligent. Precisely, knowledge is constructed from remembering, analyzing, anticipating and reproducing, in such a way that the human being builds his knowledge in charitable matters and in others that are rather negative [1].

Fights with fists, teeth and nails, could hardly provoke death; they were limited, if anything, to mutilations. But the memories combined with foresight, allowed the development of different kinds of weapons, from the most rudimentary as the stones attached to ropes, to spears and arrows with stone tips. Up to here it was an ingenious use of what nature put at hand and we can even ask ourselves if that rudimentary (in appearance) knowledge of physics (two bodies cannot occupy the same space, parabolic shot, for example) was developed as an offensive-defensive means against its peers or if it did so as an auxiliary mechanism to obtain sustenance, that is, to help in the hunt; It is very difficult to establish if these weapons were generated by the need for food or the need to show the tribe who was the boss, without a doubt. It is very possible that it was for both reasons, simultaneously, but the indisputable fact is that the development of science was linked to war from its inception $[2,3]$. Thus, the incipient development of metallurgy allowed to replace the old stone and the fragile trunk by bronze armament (around $160 \mathrm{BC}$ ), much harder and more resistant; Then came the iron. When the tribes stopped being nomadic and became sedentary, the struggles were generated by the possession of the best lands and the tribal conflict worsened. Fertile lands were required to sow and practice grazing and frequently (until our days) it was easier to steal the good lands (with animals and inhabitants, which provided free labor) than to dismantle, prepare, etc. As the weapons began to be perfected, the study of art or military science arose.

The situation prevailed in the simple improvement of metal weapons fundamentally (arrows with bow and crossbow, spears), as well as protection systems (shields, helmets), until another scientific discovery allowed a breakthrough considerably important: the invention of gunpowder. It is attributed to the Chinese having invented it and we have data that by the year 1160 was used in fireworks; there is information that five centuries before the invention of gunpowder, the Byzantine Empire had an incendiary chemical weapon called "Greek fire", a mixture of ingredients that are not known exactly (the only thing that is known with certainty is that it was used in liquid form, expelled through a kind of syringe and against wooden structures), which had the quality of burning in water. It is known that this weapon was used to repel the Arabs and the Russians, saving Constantinople from the invasions. However, its great difference with gunpowder lies in two primary factors: the secret in the constitution and management of its components its use was limited to the Byzantines, and it was a fundamentally incendiary weapon, while the use of Gunpowder spread throughout the world, and it is an explosive. It was in Europe that gunpowder went from fireworks to a mechanism of propulsion and it became 
obsolete to throw rocks with a catapult, with the canyon emerging as a substitute. Slowly improvements were made to gunpowder and guns, enabling the design of artillery pieces that would not pose a risk to the gunner; the use of gunpowder came to dominate the battlefields from the end of the $15^{\text {th }}$ century, doing so for four more centuries, until the end of the $19^{\text {th }}$ century [4].

It was in that century that new explosives such as nitroglycerin, trinitrotoluene (TNT) and gunpowder (white powder or smokeless gunpowder) were developed, ending with the warrior kingdom imposed by gunpowder. During all that time of reign, arose the musket, the carabiner, the arquebus, the rifle, the pistol, the revolver, among other firearms, in addition to the increasingly sophisticated versions of the cannon. The First World War brought the use of airplane, tank and poisonous gases, such as chlorine and mustard. World War II introduced perfected versions of aircraft, ships, submarines, tanks and explosives, dominating the scene his majesty: the atomic bomb. From the surrender of the countries of the axis, technology has played an increasingly important role in the military field. Advances in communications and the development of vaccines, for example, have also served to improve the standards of living of certain social classes, as well as to military systems throughout the world. Technological development has influenced the ways of waging war, without modifying its principles. Spy satellites (taking pictures from outer space), anti-missile missiles (to defend against directed projectiles), particle or laser-type weapons (almost pure energy), advanced ballistic re-entry vehicles (sent to outer space that change its trajectory before re-entering the Earth's atmosphere), extended radiation weapons (neutron bombs), multiple re-entry vehicles with independent targets (they are also sent to outer space, where they deploy different warheads with different destinations, complicating the work of the missiles anti-missiles), even conventional weapons classified as short have been increasingly perfected, for the benefit and complacency of the military. Aviation, communications, almost all scientific development has had a military prototype or has culminated in one of them. Internet (free access computerized worldwide network) was originally ARPANET (computer network sponsored in the late1960s by the Secretary of Defense of the United States, which had as its first nodes the Universities of Stanford and UCLA, followed quickly by the UTA, for the purpose of military research in defense matters), exclusively military use network. The alliances that emerged at the end of the Second World War determined, to a large extent, what has been researched and developed in the political, economic and scientific fields since then $[5,6]$.

And the environmental effects caused by military activities? Devastation of farmland, air, water and land pollution, all caused by the use of chemical weapons; the combustion of hydrocarbons; the use of explosives and incendiary weapons; the tests of nuclear devices and the eventual escape of organisms designed for biological warfare, among others, are aspects that must be taken into account.
The world peace that we all want, should not be limited merely to the state of absence of war, should be understood as an unrestricted respect for our biosphere, so that this lack of ecological awareness will not be reversed against us. And it is tremendous the problem that arises to get rid of what has been stored for decades and now must be destroyed. The remediation of contaminated areas is a part of science closely related to the development of weapons. For centuries science and war have walked hand in hand. Sometimes it has happened in a random way, as in the discovery of some neurotoxic gases by the Germans, but it has not always been a fortuitous relation, the development of NAPALM was the result of an investigation destined precisely for that purpose, financed by the army and developed at Harvard, among other illustrious scientists, by Louis F. Fieser. NAPALM, first reported in 1942, is a gelatinous substance that adheres extraordinarily strongly to the surface on which it is deposited, as it is consumed by fire, much more slowly than when gasoline is burned alone. Originally it was a mixture of gasoline with aluminum soaps made from coconut oil (hence its name by Naphthenate and aluminum PALMitato), but with time it was perfected, and a mixture of polystyrene and benzene was used to gelatinize the gasoline and generate more heat when you burn it.

Before the question of whether it was ethical to orient scientific work to a totally destructive desire, because NAPALM has no beneficial applications, Fieser replied: "A researcher is not responsible for the way in which other people use their inventions. One does not know what comes next. I worked on a technical problem that was considered important and, if they proposed it again, I would accept it again, in defense of my country. "So, the ethical problem is reduced to a struggle of values in which the winner is patriotism.

Many are the advances that we can question from their origin, although in the end they have dual applications. Cartography and maps, were developed to know the contour of the lands, islands, continents, or to have perfectly located the enemy and the army itself? The telegraph and the telephone, did they arise from a scientist motivated to bring people closer and allow them to communicate more quickly, or were they created to carry messages through the enemy lines without danger of losing the messenger? The message could be lost as well, so cryptography was developed. Increasingly complex, the moment arrived in which to decipher a coded message it became necessary to have a machine fast enough for it. Was that machine the ancestor of the computer, or was the abacus and the adding machine? Chemical weapons led to the development of antigas masks, which now employ many workers in some industries, such as paints, as normal protective equipment. But also led to personal protective equipment, vital in the development of the protective suits used by all astronauts, especially when they are in space walks. This relationship of dependence between science and war must change, because if it does not, the future is not promising. Nanotechnology allows us to think about weapons of 
that size, but the current risk does not end there. The knowledge of the genetic code, the manipulation of microorganisms and genetic engineering could be combined to generate a biological weapon that would attack only a certain stratum of the world population with a gene of that population nucleus, fulfilling in some way the murderous dream of Hitler, the struggle for the supremacy of a race, a dream that apparently is now the American dream, or rather, the USA (Donald Trump) dream. And that, really, is something to take anybody's sleep.
2. Christopher Chant (1980) There is an extremely old engraving in a Byzantine manuscript that reproduces a scene of use of the Greek fire. How weapons work. Marshal Cavendish Limited (2 $2^{\text {nd }}$ Edn) Hong Kong p. 9.

3. Alfonso Corona del Rosal (1989) Diversos temas histórico militares. Editorial Grijalbo (1 ${ }^{\text {st }}$ Edn $)$ México, pp. 125-128.

4. Alfonso Corona del Rosal Op cit, pp. 129-131.

5. Robert Berman, Bill Gunston (1983) Rockets and missiles of world war III Exeter Books New York, USA.

6. Jay Miller (1991) Northrop B-2 stealth bomber Specialty Press, USA.

\section{References}

1. John Keegan (1994) A history of warfare. $\left(5^{\text {th }}\right.$ Edn) Alfred A Knopf, Inc., New York, USA.

\section{cc) (i) \\ This work is licensed under Creative Commons Attribution 4.0 License}

Submission Link:

Submit Article

DOI: $10.32474 /$ DDIPIJ.2018.02.000142

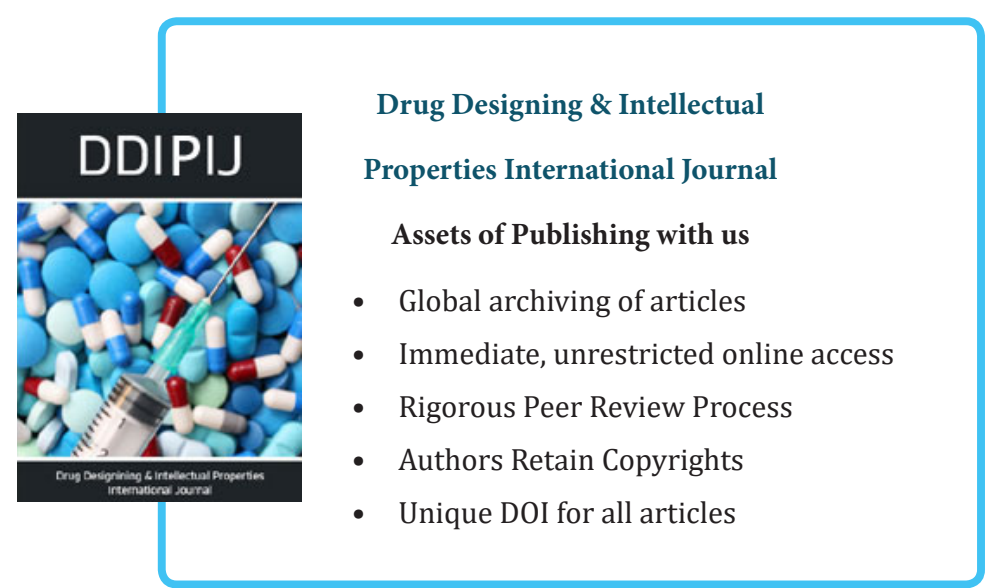

